\title{
GELENEKSEL GIDALARDAN DARTI'NIN ÜRETİM YÖNTEMİ VE BAZI ÖZELLIKLERİNİN BELİRLENMESİ
}

\author{
Öznur Cumhur* \\ Bilecik Şeyh Edebali Üniversitesi, Uygulamalı Bilimler Fakültesi, Bilecik, Türkiye
}

Geliş / Received: 18.01.2019; Kabul / Accepted: 18.07.2019; Online bask1 / Published online: 26.07.2019

Cumhur, Ö. (2019). Geleneksel gıdalardan darti'nın üretim yöntemi ve bazı özelliklerinin belirlenmesi. GIDA (2019) 44 (4): 733-741 doi: 10.15237/gida.GD19024

Cumbur, Ö. (2019). Determination of production method and some characteristics of darti from traditional foods. GIDA (2019) 44 (4): $733-741$ doi: 10.15237/gida.GD19024

\section{ÖZ}

Bu çalışmada, geleneksel bir gıda olan dartının üretiminin kayıt altına alınması, bileşim ve duyusal özelliklerinin belirlenmesi, ürünün kalitesini kaybetmeden üretilmesi ve zamanla kaybolmasının önlenmesi hedeflenmiştir. Dart; çiğ süt kremasından pişirilerek yapılan, kendine özgü tat ve aroması olan geleneksel bir gıdadır. Ürün yaygın olarak kahvaltıda tüketilmekte; pilav, makarna ve yöresel bir ürün olan keşkekte sos olarak kullanılmakta veya yemek ve hamur işlerinde yağ olarak ikame edilmektedir. Çalışma kapsamında dartının üretimi incelenmiş, tuzlu ve tuzsuz olarak üretilen ürünün kontrollü şartlarda geleneksel üretimi gerçekleştirilmiştir. Ürünlerde kül, kuru madde, protein, yağ, $\mathrm{pH}$, titrasyon asitliği analizleri yapılmış ve duyusal özellikleri değerlendirilmiştir. Tuzlu olarak üretilen üründe kül, kuru madde, protein, yağ, $\mathrm{pH}$ ve titrasyon asitliği değerleri sırasıyla $\% 2.66, \% 85.93, \% 8.61, \% 66.33,4.34$ ve $\% 1.05$ olarak bulunmuştur. Ürünü tanımayan tüketicilere uygulanan duyusal analiz sonuçlarına göre; dartı genel olarak görünüş, koku, kıvam ve yapı açısından orta düzeyde beğenilirken; tat olarak en yüksek puanı alarak tüketicinin beğenisini kazanmıştır. Anahtar kelimeler: Geleneksel gida, dart1, kaymak kavurması.

\section{DETERMINATION OF PRODUCTION METHOD AND SOME CHARACTERISTICS OF DARTI FROM TRADITIONAL FOODS}

\begin{abstract}
In this study, it is aimed to record the production of dart1, which is a traditional food, to determine the composition and sensory properties of it, to produce without losing the quality of the product and to prevent its disappearance in time. Dartı with its own taste and flavor, is made by cooking raw milk cream. The traditional food is widely consumed in the breakfast, served as a sauce on rice, pasta, and a local product keşkek or substituted fat for food and pastries. In the study, production of dartı was investigated and traditional production of the salted and unsalted product was carried out under controlled conditions. The ash, dry matter, protein, fat, $\mathrm{pH}$, titration acidity of the products were studied and their sensory properties were evaluated. The ash, dry matter, protein, fat, $\mathrm{pH}$ and titration acidity values of the traditional food produced as salty were found to be as $\% 2.66, \% 85.93, \% 8.61$, $\% 66.33,4.34$ and $\% 1.05$, respectively. According to the sensory analysis results applied to consumers who do not know the product; dartı moderately evaluated in terms of appearance, smell, consistency and structure; got the highest score regarding the taste and won the appreciation of consumers.
\end{abstract}

Keywords: Traditional foods, dart1, roasted cream.

\footnotetext{
* Yazışmalardan sorumlu yazar / Corresponding author;

$\varangle$ oznur.cumhur@bilecik.edu.tr @ (+90) 2282141985

岛 $\quad(+90) 2282141302$
} 


\section{GíRIŞ}

Gastronomik mirasın bir parçası olan geleneksel gıdalar, gıda pazarında yer alan çok fazla çeşitlilikteki ürünlerin arasında tüketiciler tarafindan tercih edilen ve pazarda büyüyen bir alanı temsil etmektedir. Tüketiciler geleneksel gıdaları sağlıklı, besleyici, güvenli, yüksek kaliteli, lezzetli, doğal, çevre dostu, benzersizlik gibi gida tüketimi açısından olumlu özelliklerle ilişkilendirmekte ve bu durum ürünlere pazarda bir avantaj sağlamaktadır (Trichopoulou vd., 2007; Belc vd., 2016; Onurlubaş ve Taşdan, 2017). Geleneksel gidalarda geleneksel malzemelerin kullanılmasi; üretim, sunum, tüketim ve/veya saklama koşullarının coğrafyaya özgü olması ürünü pazardaki diğer ürünlerden farklılaştırmakta ve ürüne ayırt edici özellikler kazandırmaktadır (Cumhur, 2017).

Dartı Kocaeli, Sakarya, İzmir ve Antalya gibi yörelerde Manav kültüründeki insanlar tarafindan aile ekonomisi içerisinde çiğ inek sütü kremasından pişirilerek yapılan, pişirmeden dolayı kendine has tat ve aroması olan geleneksel bir süt ürünüdür. Ürün yaygın olarak kahvaltıda ekmekle tüketilirken; pilav, makarna ve yöresel bir yemek olan keşkekte sos olarak sunulmakta; hamur işleri, yumurta ve yemeklerde yağ olarak ikame etmektedir (Cumhur, 2018). Dartının hammaddesinin süt yağının oluşturduğu kaymak olması ve üretim aşamasında kaymakla beraber olan süt bileşenlerinin kavrulması sebebiyle ürün kaymak kavurması olarak da adlandirılmaktadır. Ayrıca ürün farklı yörelerde tartı, süt katığı gibi isimlerle de anılmaktadır.

Tüm dünyada olduğu gibi ülkemizde de geleneksel gidalar değişen teknoloji ve tektipleşen beslenme alışkanlıkları nedeniyle yok olma riski altındadır. Bu nedenle, kültürümüzün bir parçası olan geleneksel gidaları incelemek ve belgelemek önemlidir. Bu bağlamda geleneksel gidalarla ilgili birçok çalışma yapılmaktadır. Ancak dartıyla ilgili tarama yapıldığında az sayıdaki çalışmada ürün yer almaktadır.

Türk Patent Enstitüsü'nün coğrafi işaret tescil belgesi verdiği "Adapazarı Dartıll Keşkek" yöresel yemeğinde üründen yardımc1 eleman olarak bahsedilirken (Anonymous, 2009); "Akçakoca
Melengücceği Tatlısı"nda üründen tatlının içinde süt kaymağının kızartılması sonucunda elde edilen ve tatliya asıl lezzetini veren iç malzeme olarak bahsedilmektedir (Anonymous, 2017). Kocaeli ve Kandıra yöresine ait gastronomik lezzetlerle ilgili yapılan çalışmalarda da dartının mutfakta hangi yemeklerde kullanıldığından ve yapımından temel düzeyde bahsedilmektedir (Alyakut \& Üzümcü, 2017; Üzümcü vd., 2017). Dartıyla ilgili ürün bazında yapılan nitel ve gözleme dayalı çalışmada ise geleneksel üründen, üretiminden, mutfakta kullanıldığı yiyeceklerden ve hangi kültüre ait olduğundan bahsedilmektedir (Cumhur, 2018).

Bu çalışmada, dartı üreticileri ile birlikte geleneksel olarak üretimi yapılmıs ve üretim yöntemi kayıt altına alınmıştır. Geleneksel üretimin kontrollü şartlarda yapıldığı örneklerde bazı fiziksel, kimyasal ve duyusal analizler yapilarak geleneksel ürüne özgü karakterizasyon çalışmalarına yer verilmiştir. Fiziksel ve kimyasal sonuçlar, geleneksel ürünle aynı hammaddeden üretilen kaymak ile karşılaştırılmıştır. Böylece geleneksel bir gida olan dartının kalitesini kaybetmeden üretiminin sağlanması, ürüne standart kazandırılması adına kaynak oluşturulması ve tüketiciler tarafindan ürünün duyusal olarak değerlendirilmesi sağlanmıştır.

\section{MATERYAL VE YÖNTEM \\ Dartının geleneksel üretim şeklinin belirlenmesi}

Çalışmada geleneksel olarak üretilen dartıyla ilgili üreticilerden bilgiler temin edilmiş, üretim aşamaları gözlemlenmiş ve üretim kayıt altına alınmıştır. Geleneksel dartının üretimi Manav kültürüne özgü olduğu için, ilgili araştırma özellikle ürün üretiminin yaygın olarak yapıldığı ve Manav kültürünün hakim olduğu Sakarya'da yapılmıştır. Ürün üretiminde kullanılan çiğ süt kreması ve tuz miktarı, üretim sırasındaki sıcaklık (TFA 14.1503 Dijital Termometre) ve süre gibi üretim koşulları belirlenmiştir. Ardından ürün üretimini bilen ve yapan iki kişi tarafindan üç ayrı zamanda geleneksel gidanın üretimi tuzlu ve tuzsuz olarak kontrollü şartlarda gerçekleştirilmiştir. Dartı örnekleri analizleri yapılana kadar buzdolabı koşullarında muhafaza edilmiş ve tüm analizler 5 gün içerisinde tamamlanmıştır. 


\section{Çiğ süt kreması ve kontrollü şartlarda üretilen} dartıda yapılan bileşim analizleri

Hammadde olarak kullanılan çiğ süt kreması ve kontrollü şartlarda üretilen tuzlu ve tuzsuz dart1 örneklerinde kuru madde tayini TS 1018'de belirtilen gravimetrik yöntemle (Anonymous, 2002), kül miktarı AOAC 945.46'ya göre (Anonymous, 2000), yağ oranı TS 2446'ya uygun olarak Gerber yöntemiyle (Anonymous, 2015), titrasyon asitligi TS 1018'e göre \% laktik asit cinsinden (Anonymous, 2002) ve toplam azot miktar1 TS EN ISO 8968-3'e uygun olarak (Anonymous, 2008) Kjeldahl yöntemiyle belirlenmiştir. Toplam azot miktarı, 6.38 faktörüyle çarpılarak protein oranı hesaplanmıştır. Örneklerin $\mathrm{pH}$ değerleri için $28^{\circ} \mathrm{C}$ sıcaklıkta İnolab WTW (Weilheim, Almanya) marka dijital pH metre kullanılmış ve doğrudan ölçüm yapılmıştır.

\section{Duyusal analiz}

Kontrollü şartlarda geleneksel üretimi gerçekleştirilen tuzlu dartı örneklerinde ürünü taniyan ve tanımayan tüketicilerle ayrı olarak duyusal analiz yapilmışır. Duyusal analiz öncesi panelist grupları bilgilendirilmiş, geleneksel ürün örnekleri tüketicilere 1sitılarak $32-35{ }^{\circ} \mathrm{C}$ sicaklık aralı̆̆ında tuzsuz ekmek ve su ile birlikte sunulmuştur.

Geleneksel ürünü tanımayan tüketicilerin kabul edilebilirliğini ölçmek için tüketici testi yapılmıştır. Ürünü tanımayan tüketicilere üç kısımdan oluşan bir anket formu uygulanmıştır (Şekil 1). İlk kısımda cinsiyet, yaş ve eğitim gibi demografik özelikleri belirlemeye yönelik üç ifadeden oluşan bir soru grubu ve ikinci kısımda gidada yenilik korkusu (neofobi) düzeylerini ölçmeyi amaçlayan bir anket uygulanmıştır. Ürünü ilk kez tadacak kişilerden gıda neofobisi olanların geleneksel ürüne karşı kabul etmeme veya sakınma eğilimi gösterebilecekleri ve bu durumun tüketici testine etki edebileceği düşünüldüğü için Gıdada Yenilik Korkusu Ölçeği uygulanmıştır. Bu kapsamda kullanılan Gıdada Yenilik Korkusu Ölçeği, Pliner ve Hobden'in (1992) hazırlamış olduğu çalışmadan edinilmiş ve geleneksel ürünü tanımayan tüketicilerin yeni gidaları deneme isteği öngörülmeye çalışılmıştır. Gıdada Yenilik
Korkusu Ölçeği’nde gıda ve g1da tüketimiyle ilgili durumlar hakkında beş neofilik ve beş neofobik ifadeden oluşan toplam on madde bulunmaktadır. Ölçek 7'li Likert tipi derecelendirmeye sahip olup; "kesinlikle katılmiyorum", “ katılmiyorum”, "kismen katilmiyorum", "ne katiliyorum ne katılmiyorum", "kismen katiliyorum", "katılıyorum" ve "kesinlikle katıllyorum" şeklinde derecelendirilmiştir. Son aşamada ise tüketicilerin geleneksel ürünü görünüş, kıvam/yap1, koku, tat ve genel beğeni özellikleri yönünden 1 ile 5 puanlık hedonik skalada (1: Hiç beğenmedim, 2: Orta derecede beğenmedim, 3: Ne beğendim ne beğenmedim, 4: Orta derecede beğendim, 5: Çok beğendim) değerlendirmeleri ve düşük puan kriterlerini ifade etmeleri istenmiştir. Geleneksel olarak üretilen dartıyı tanımayan 93 kişi çalışmanın örneklemini oluşturmaktadır.

Dartının üretimini bilip tüketen kişilerin de, bu çalışma kapsamında üretilen ürünü görünüş, kıvam/yapı, koku, tat ve genel beğeni özellikleri açısından değerlendirmeleri istenmiştir. Geleneksel olarak ürünü üreten ve tanıyan 10 'u kadın ve 4'ü erkek toplam 14 kişiye ulaşılmıştır.

\section{İstatistiksel analiz}

Fiziksel, kimyasal ve duyusal analizler ile elde edilen verilerin istatistiksel analizi SPSS 22.0 (IBM, 2013) istatistiksel paket program1 kullanılarak yapılmıştır. Tuzlu ve tuzsuz dartı örneklerinin analiz sonuçlarının karşılaştırmalarında Mann-Whitney U testi kullanılmıştır. Duyusal analiz sonuçlarında gıda neofobisi olan ve gida neofobisi olmayan tüketicilerin duyusal analizlerine ilisskin karşılaştırmalar t-testi ile yapılmıştır.

\section{BULGULAR VE TARTIŞMA}

Dartının üretim yöntemi

Geleneksel olarak dartı üretiminde çiğ süt kreması ve tuz kullanılır. Çiğ inek sütünden toplanan süt kreması düşük ateşte sürekli karıştırılarak 1sıl işleme maruz birakılır. Bu ısıl işlem sırasında, krema öncelikle kaynama noktasina $\left(100-101^{\circ} \mathrm{C}\right)$ erişir ve kaynayarak koyulaşır. Kaynama aşamasında yaklaşık $2.4 \mathrm{~kg}$ süt kremasına $6.5 \mathrm{~g}$ tuz (1 tatlı kaşığı) ilave edilir. Kaynama devam ederken bir süre sonra yapıdan yağ ayrilmaya 


\section{Ö. Cumhur}

başladığ1 gözlenir, sonrasında karışım içerisindeki süt bileşenleri süt yağından iyice ayrilarak daha koyu ve heterojen bir kıvama dönüşür. Ürün 107$111^{\circ} \mathrm{C}$ sıcaklık aralığında pişirilmeye devam edilir. Isıl işlem yağ içerisindeki koyu kısım kavrularak hafif sarıdan kahverengiye dönen renge ve gözenekli bir yapıya dönüşene kadar devam eder. $2.4 \mathrm{~kg}$ kremadan yapılan dartı için 1 sıl işlem süresi yaklaşık 100-135 dakikadır. Isıl işlem sonrasında ürün ocaktan direkt soğuk bir zemine alınarak, sıcak yağın içerisindeki tortu kısmın daha fazla kavrulmas1 engellenir. Elde edilen ürün (Şekil 2) saklama kaplarına alınarak oda sıcakliğına gelinceye kadar soğumaya bırakilır. Geleneksel ürün soğuduğunda ürün kısmen donmuş olup; süt yağ1 üstte, tortu kısım altta kalan heterojen bir yapıya dönüşür. Ürün buzdolabı koşullarında saklanır. Geleneksel ürünün tüketilmesi için tekrar 1sıtılması gerekir, soğuk tüketilemez.

\begin{tabular}{|c|c|c|c|c|c|c|c|c|c|c|}
\hline \multicolumn{11}{|c|}{$\begin{array}{l}\text { Adı Soyadı: } \\
\text { Cinsiyetiniz: Kadın ( ) } \text { Erkek ( ) } \\
\text { Yaşınız: ............. } \\
\text { Eğitim Durumunuz: } \\
\text { 1. Illkokul-ortaokul mezunu } \\
\text { 2. Lise mezunu } \\
\text { 3. Üniversite mezunu } \\
\text { 4. Lisansüstü (yüksek lisans / doktora / uzmanlık) } \\
\text { 1. GIDALARDA YENILLIK KORKUSU ÖLÇEĞİ } \\
\text { Lütfen gıda neofobisi hakkında aşağıda verilen ifadeleri okuyup bu ifadelerle ilgili cevap kağıdında } \\
\text { belirtilen tanımlamalardan uygun olanın (yalnızca bir seçeneğin) altındaki parantez arasına (X) işaret } \\
\text { koyunuz. }\end{array}$} \\
\hline & & & & 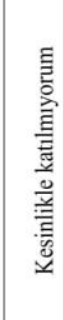 & 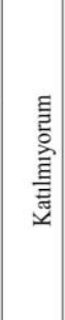 & 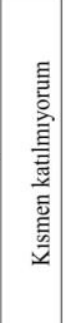 & 吾 & 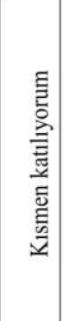 & 豆 & 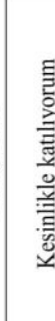 \\
\hline \multicolumn{4}{|c|}{ 1.Sürekli olarak yeni ve farklı gıdaları denerim. } & $($ ) & ( ) & ( ) & ( ) & ( ) & ( ) & $($ ) \\
\hline \multicolumn{4}{|c|}{ 2.Yeni gıdalara güvenmem. } & ( ) & ( ) & ( ) & () & $($ ) & ( ) & ( ) \\
\hline \multicolumn{4}{|c|}{ 3.İçinde ne olduğunu bilmediğim gıdayı denemem. } & $($ ) & ( ) & $(\mathbf{)}$ & () & $(\mathbf{)}$ & $(\mathbf{)}$ & $($ ) \\
\hline \multicolumn{4}{|c|}{ 4.Farklı kültür ve bölgelerin gıdalarını beğenirim. } & () & ( ) & $(\mathbf{)}$ & ( ) & $(\mathbf{)}$ & $(\mathbf{)}$ & $($ ) \\
\hline \multicolumn{4}{|c|}{$\begin{array}{l}\text { 5.Farklı kültür ve bölgelerin gıdaları yemek için fazla tuhaf } \\
\text { görünüyor. }\end{array}$} & $(\quad)$ & ( ) & ( ) & ( ) & ( ) & $(\mathbf{)}$ & ( ) \\
\hline \multicolumn{4}{|c|}{ 6.Sosyal etkinliklerde yeni gıdalar denerim. } & ( ) & ( ) & ( ) & () & ( ) & ( ) & ( ) \\
\hline \multicolumn{4}{|c|}{ 7.Daha önce yemediğim gıdaları yemekten korkarım. } & $(\mathbf{)}$ & ( ) & $(\mathbf{c})$ & () & $(\mathbf{)}$ & $(\mathbf{)}$ & $($ ) \\
\hline \multicolumn{4}{|c|}{ 8.Yediğim gıdalar konusunda çok seçiciyimdir. } & () & $(\mathbf{)}$ & $(\mathbf{)}$ & () & $($ ) & $($ ) & ( ) \\
\hline \multicolumn{4}{|c|}{ 9.Yemek seçmem, neredeyse her şeyi yerim. } & $(\mathbf{)}$ & ( ) & $(\mathbf{)}$ & ( ) & ( ) & $(\mathbf{)}$ & $($ ) \\
\hline \multicolumn{4}{|c|}{$\begin{array}{l}\text { 10. Farklı kültür ve bölgelerin yiyecek ve içeceklerini sunan } \\
\text { restoranlarda yeni tatlar denemeyi severim. }\end{array}$} & ( ) & ( ) & ( ) & ( ) & ( ) & ( ) & ( ) \\
\hline \multicolumn{11}{|c|}{ 2. DUYUSAL DEĞERLENDİRME FORMU } \\
\hline \multicolumn{11}{|c|}{$\begin{array}{l}\text { Size verilen geleneksel bir ürün olan dartıyı aşağıdaki kriterlere göre } \mathbf{5} \text { puan üzerinden } \\
\text { değerlendiriniz. } 5 \text { 'ten düșük puan verdiyseniz puan düşürücü kriterinizi yazınız. }\end{array}$} \\
\hline \multicolumn{4}{|c|}{ Değerlendirilen Özellikler } & \multicolumn{7}{|c|}{ Puan (1-5) } \\
\hline \multicolumn{11}{|c|}{ Görünüş } \\
\hline \multicolumn{11}{|l|}{ Kivam ve Yapı } \\
\hline \multicolumn{11}{|l|}{ Koku } \\
\hline \multicolumn{11}{|l|}{ Tat } \\
\hline \multicolumn{11}{|l|}{ Genel Beğeni } \\
\hline $\begin{array}{c}\text { Puan değerleri } \\
\text { ile ilgili } \\
\text { açıklamalar }\end{array}$ & $\begin{array}{l}\text { 5. Çok } \\
\text { beğendim }\end{array}$ & $\begin{array}{l}\text { 4. Orta derecede } \\
\text { beğendim }\end{array}$ & $\begin{array}{l}\text { 3. Ne beğe } \\
\text { ne beğenm }\end{array}$ & endim & 2. Or & $\begin{array}{l}\text { rta der } \\
\text { ğenme }\end{array}$ & $\begin{array}{l}\text { recede } \\
\text { edim }\end{array}$ & & $\begin{array}{l}\text { 1. } \mathrm{Hi} \\
\text { :ğenme }\end{array}$ & iç \\
\hline
\end{tabular}

Șekil 1. Geleneksel gidanın değerlendirilmesinde kullanılan örnek form. Figure 1. Sample form used in the evaluation of traditional food. 


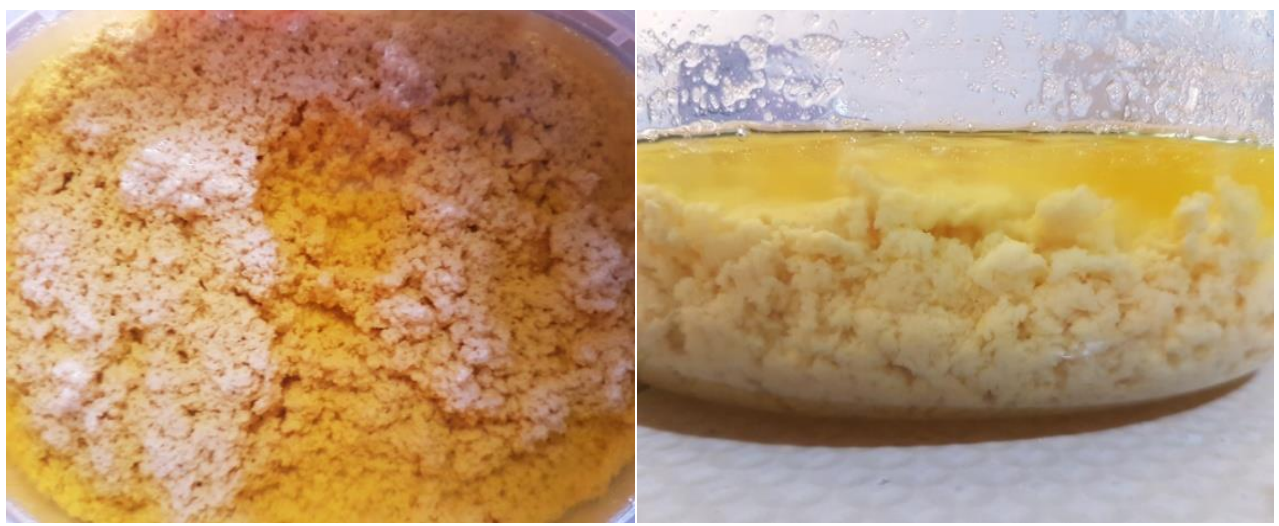

Şekil 2. Heterojen yapıdaki geleneksel dartı örneği.

Figure 2. Example of a traditional dart in a heterogeneous structure.

\section{Bileşim analizleri}

Ürün üretiminde kullanılan ağırlıkça \%24.5 yağ içeren çiğ inek sütü kremas1; ortalama \%2.79 protein, $\% 29.91$ kuru madde, $\% 0.57$ kül içermekte olup; titrasyon asitliği \%0.60 ve $\mathrm{pH}$ 's1 4.50 'dir. Smiddy vd. (2009) \%25 yağ içeren kremada \%31.5 kurumadde, $\% 2.5$ protein ve $\% 0.5$ kül belirlemiş olup, bu konsantrasyonların artan yağ içeriği ile azaldığını belirtmişlerdir.

Kontrollü şartlarda ve üç farklı zamanda geleneksel üretilen tuzsuz ve tuzlu dart1 örneklerinde yapılan analiz sonuçları Çizelge 1'de verilmiştir. Yapılan çalışma kapsamında dartının kurumadde içeriği tuzsuz örneklerde \%83.05$\% 92.13$, tuzlu örneklerde \%84.13-\%87.38 aralı̆̆ında tespit edilmiştir. Piyasada satışa sunulan kaymak örneklerinde kuru madde miktarını Öksüz vd. (2000) \%63.50-\%74.00 olarak belirlenmişken, Akalın vd. (2006) \%67.80-\%77.55 olarak belirlemiştir. Kocaoğlu (2009) ise farklı mevsimlerde toplanan endüstriyel kaymak örneklerinde kuru madde miktarının \%52.63\%72.11 arasında değiştiği belirtmiştir. Ürünün kuru madde miktarının piyasada satışa sunulan kaymakların kuru madde miktarından yüksek olması, geleneksel ürüne uygulanan 1sıl işlemden kaynaklandığı düşünülmektedir.

Çizelge 1. Tuzsuz ve tuzlu dartı örneklerinin kimyasal ve fiziksel özellikleri. ${ }^{1}$

Table 1. Chemical and physical properties of unsalted and salted dart samples. ${ }^{1}$

\begin{tabular}{|c|c|c|c|c|c|c|}
\hline $\begin{array}{l}\text { Örnek } \\
\text { Sample }\end{array}$ & $\begin{array}{l}\text { Kurumadde }(\%) \\
\text { Dry Matter }\end{array}$ & $\begin{array}{l}\text { Protein }(\%) \\
\text { Protein }\end{array}$ & $\begin{array}{c}\text { Yağ }(\%) \\
\text { Fat }\end{array}$ & $\begin{array}{c}\text { Kül (\%) } \\
\text { Ash }\end{array}$ & $\begin{array}{c}\text { Titrasyon } \\
\text { Asitliği }(\%) \\
\text { Titration Acidity }\end{array}$ & $\mathrm{pH}$ \\
\hline $\begin{array}{l}\text { Tuzsuz Geleneksel } \\
\text { Üretim } \\
\text { Unsalted Traditional } \\
\text { Production }\end{array}$ & $87.33 \pm 4.56^{\mathrm{a}}$ & $8.96 \pm 0.43^{a}$ & $68.33 \pm 2.08^{a}$ & $1.94 \pm 0.05^{\mathrm{b}}$ & $1.35 \pm 0.04^{\mathrm{a}}$ & $4.47 \pm 0.21^{\mathrm{a}}$ \\
\hline $\begin{array}{l}\text { Tuzlu Geleneksel } \\
\text { Üretim } \\
\text { Salted Traditional } \\
\text { Production }\end{array}$ & $85.93 \pm 1.65^{\mathrm{a}}$ & $8.61 \pm 0.32^{\mathrm{a}}$ & $66.33 \pm 3.51^{\mathrm{a}}$ & $2.66 \pm 0.07^{\mathrm{a}}$ & $1.05 \pm 0.36^{\mathrm{a}}$ & $4.34 \pm 0.19^{a}$ \\
\hline
\end{tabular}

1: Ortalama \pm standart sapma.

a,b: Aynı sütunda farklı harflerle gösterilen ortalama değerler birbirinden farklıdır $(P \leq 0.05)$.

${ }^{1}:$ Mean \pm standard deviation.

${ }^{a, b}$ : The mean values shown in different letters in the same column are different $(P \leq 0.05)$.

Tuz eklenen ve eklenmeyen dartı örneklerinde kül miktarı değerleri karşılaştırıldığında farklılık önemli düzeyde bulunmuştur $(P \leq 0.05)$. Tuzsuz dartı örneklerinde kül oranı ortalama \%1.94 iken; tuzlu dartı örneklerinde kül oranı ortalama \%2.66 ile daha yüksektir. Eklenen tuz miktarının kül 
oranına etki ettiği düşünülmektedir. Tuzlu dart1 örneklerinde protein oranlar1 $\% 8.29$ ve $\% 8.92$ arasında değişirken, tuzsuz dartı örneklerinde protein oranlarınin $\% 8.53-\% 9.39$ arasinda değiştiği görülmektedir. Piyasada satışa sunulan kaymakların protein değerlerindeki farklılıkların kuru madde miktarına bağlı olduğu bildirilmiş olup (Pamuk, 2017), dartıda da protein miktarındaki farklılıkların benzer şekilde değişen kuru madde miktarıla ilişkili olduğu düşünülmektedir.

Tuzlu dartı örneklerinde yağ oranları $\% 66$ ve $\% 70$ arasında değişirken, tuzsuz dartı örneklerinde yağ oranlarının \%63 ve \%70 arasında değiştiği görülmektedir. Türk Gıda Kodeksi Krema ve Kaymak Tebliği (Anonymous, 2003) kapsaminda piyasada satışa sunulan kaymakta kütlece en az $\% 60$ oranında süt yağı bulunması gerekmektedir. Temelde süt kremasindan yapilan dartı tebliğ kapsamında satışa sunulmasa da, yağ içeriği bu alt sınır değerinden yüksektir. Geleneksel olarak üretilen dartı piyasada satışa sunulan kaymaklarla eş değer yağ oranına sahiptir. Bu durum heterojen yapıya sahip olan kütlece $100 \mathrm{~g}$ dartı örneğinde, 63-70 g yağ ve ortalama $13.4 \mathrm{~g}$ su emülsiyonu içerisinde yaklaşık 16.6-23.6 g yağ ve su dış1 bileşenlerin olduğunu göstermektedir.

Dartı örneklerinin $\mathrm{pH}$ ve \% laktik asit cinsinden titrasyon asitliği değerlerinin sirasıyla tuzsuz örneklerde $\quad 4.31-4.71$ ve $\% 1.31-\% 1.38$ aralı̆̆ındayken; tuzlu örneklerde 4.19-4.56 ve $\% 0.80-\% 1.46$ aralığında değişim gösterdiği tespit edilmiştir. İstatistiksel değerlendirme sonucunda, tuz eklemenin ürünün $\mathrm{pH}$ değeri ve titrasyon asitliği bulgularına etkisinin önemsiz olduğu belirlenmiştir $(P>0.05)$. Piyasada satışa sunulan kaymaklarla ilgili yapılan çalışmalarda Akalın vd. (2006) örneklerinin $\mathrm{pH}$ değerlerinin 6.20-7.20 arasında değiştiğini, Kocaoğlu (2009) örneklerinin $\mathrm{pH}$ değerlerinin 6.08-7.63 arasında değistiğini, Dereli ve Şevik (2011) örneklerinin pH değerlerinin 5.12-6.95 arasında değiştiğini saptamıştır. Kaymak örneklerinde laktik asit cinsinden titrasyon asitliği, Kocaoğlu (2009) tarafindan incelenen örneklerde \%0.43-\%0.27 arasında değişirken; Öksüz vd. (2000) tarafından incelenen örneklerde \%0.17-\%0.58 arasinda değiştiği belirlenmiştir. Geleneksel ürün 1sıl işlem görmüş krema olup $\mathrm{pH}$ değerinin kaymak örneklerine göre düşük olduğu ve titrasyon asitliğinin de daha yüksek olduğu görülmektedir. Üründe asitliğin yüksek olması üretimde kullanılan ve toplanan çiğ süt kremasına sütün sağılması, yağın toplanmas1 ve bekletme koşullarında bulaşan çeşitli mikroorganizmaların faaliyet göstermesinden ve/veya geleneksel üretim tekniklerinden kaynaklanabileceği düşünülmektedir. Buzdolabı koşullarında muhafaza edilen kaymak örneklerinde asitlik derecesinin üçüncü günden itibaren arttığ1, ancak -5 ile $0^{\circ} \mathrm{C}$ arasındaki sıcakliklarda asitliğin sabit kaldığı belirtilmiştir (Pamuk, 2017).

\section{Duyusal değerlendirme}

Duyusal değerlendirmenin ilk kısmında; üretilen ve analizleri gerçekleştirilen geleneksel dartının, ürünü tanıyan tüketiciler tarafindan kabul edilen duyusal özelliklere sahip olup olmadığının analiz edilmesi ve tüketicilerin genel beğenisinin ortaya konulması amaciyla tuzlu üretilen dartı örneklerine duyusal analiz yapılmıştır.

Ürünü tanıyan ve üretimini yapan 14 tüketicinin geleneksel ürünle ilgili duyusal analiz bulguları ve ortalama değerleri Çizelge 2'de yer almaktadır. Ürünü taniyan tüketiciler kokuya tam (5) puan verirken, ikinci olarak tadina ortalama 4.93 ile en yüksek puanı vermişlerdir. Ürünü tanıan tüketicilerden bir tanesi kendi ürettikleri dart1 tadının daha az ekşimsi olduğunu ifade etmiştir. Dartının görünüşü, ürünün tanıyan tüketici grubu tarafından 4.57 ile en düşük puan verilen özellik olmuştur. Dartıyı tanıyan üç tüketici üretim sırasında uygulanan ısıl işlem koşullarından dolayı, ürün renginin biraz daha kahverengiye dönebileceğini ve dağınık yap1 içerisindeki tortunun çok daha pütürlü görüntüde olabileceğini ifade etmişlerdir. Ürün genel olarak heterojen yapıda olduğu için görünüş, kıvam ve yapısıyla ilgili duyusal değerlendirmede zorlanılmaktadır. Tüketiciler genel olarak kendilerine sunulan dartı örneklerinin gereken özellikleri taşıdığını ifade etmişlerdir. 
Çizelge 2. Geleneksel ürünü tanıyan ve tanımayan (g1da neofobisi olan ve olmayan) panelistlerin duyusal analiz değerleri. ${ }^{1}$

Table 2. Sensory analysis values of panelists who know and do not know (with and without food neophobia) the traditional food. ${ }^{1}$

\begin{tabular}{|c|c|c|c|c|}
\hline \multirow[b]{2}{*}{$\begin{array}{l}\text { Özellikler } \\
\text { Properties }\end{array}$} & \multirow[b]{2}{*}{$\begin{array}{l}\text { Ürünü Taniyan } \\
\text { Panelistler } \\
\text { Tarafindan } \\
\text { Verilen Puanlar } \\
\text { Points Given by } \\
\text { Panelists Who } \\
\text { Know the Product }\end{array}$} & \multicolumn{3}{|c|}{$\begin{array}{l}\text { Ürünü Tanımayan Panelistler Tarafindan Verilen Puanlar } \\
\text { Points Given by Panelists Who do not Know the Product }\end{array}$} \\
\hline & & $\begin{array}{c}\text { G1da Neofobisi } \\
\text { Olmayan Panelistler } \\
\text { Tarafindan Verilen } \\
\text { Puanlar }^{2} \\
\text { Points Given by } \\
\text { Panelists without Food } \\
\text { Neophobia }^{2} \\
\end{array}$ & $\begin{array}{c}\text { Gida Neofobisi } \\
\text { Olan Panelistler } \\
\text { Tarafindan Verilen } \\
\text { Puanlar }^{2} \\
\text { Points Given by Panelists } \\
\text { with Food Neophobia }{ }^{2}\end{array}$ & $\begin{array}{l}\text { Ürünü Tanımayan } \\
\text { Panelistler } \\
\text { Tarafindan Verilen } \\
\text { Puanlar } \\
\text { Points Given by } \\
\text { Panelists Who do not } \\
\text { Know the Product } \\
\end{array}$ \\
\hline $\begin{array}{l}\text { Görünüş } \\
\text { Appearance }\end{array}$ & $4.57 \pm 0.51$ & $3.23 \pm 1.06$ & $3.61 \pm 1.02$ & $3.40 \pm 1.05$ \\
\hline $\begin{array}{l}\text { Kivam ve Yap1 } \\
\text { Consistency and } \\
\text { Texture }\end{array}$ & $4.71 \pm 0.47$ & $4.00 \pm 0.77$ & $3.92 \pm 0.96$ & $3.97 \pm 0.85$ \\
\hline $\begin{array}{l}\text { Koku } \\
\text { Odor }\end{array}$ & $5.00 \pm 0.00$ & $3.82 \pm 1.13$ & $3.97 \pm 1.27$ & $3.89 \pm 1.19$ \\
\hline $\begin{array}{l}\text { Tat } \\
\text { Taste }\end{array}$ & $4.93 \pm 0.27$ & $4.25 \pm 1.06$ & $3.97 \pm 1.15$ & $4.12 \pm 1.10$ \\
\hline $\begin{array}{l}\text { Genel Beğeni } \\
\text { Overall } \\
\text { Acceptability }\end{array}$ & $4.86 \pm 0.36$ & $4.02 \pm 0.96$ & $3.87 \pm 0.98$ & $3.96 \pm 0.97$ \\
\hline
\end{tabular}

Duyusal değerlendirmenin ikinci kısmında ise ürünü tanımayan 93 tüketicinin katılımıla geleneksel ürünün duyusal analizi gerçekleştirilmiştir (Çizelge 2). Geleneksel ürünü tanımayan ve duyusal analize katılan katılımcilardan \%48.4'ü kadınlardan, \%51.6's1 erkeklerden oluşmaktadır. Katılımcıların \%54.8'i 20-29 yaş aralığında, \%22.6'sı 30-39 yaş aralı̆̆ıında, \%14.0'ü 40-49 yaş aralı̆̆ında ve \%8.6's1 50 yaş ve üzeridir. Yine katılımciların \%38.7'sinin üniversite mezunu olduğu, \%37.6'sının lise mezunu olduğu, \%19.4'ünün lisansüstü eğitim aldığ1 ve \%4.3'ünün ilköğretim mezunu olduğu tespit edilmiştir.

Geleneksel olarak üretilen dartı, ürünü tanımayan tüketiciler tarafindan gida neofobisi olanlar ve olmayanlar diye iki grup altında değerlendirilmiştir. Tüketicilerden 41'inin gida neofobisi olduğu ve 52'sinin gida neofobisi olmadığ1 saptanmıştır. Ürünü ilk kez tadacak kişilerden gıda neofobisi olanların dartıya karşı kabul etmeme veya sakınma eğilimi gösterebilecekleri ve bu durumun tüketici testine etki edebileceği düşünülmüştür. Ancak görünüş, kıvam/yap1, koku, tat, genel beğeni özelliklerini kapsayan duyusal analizde gida neofobisi olan ve olmayan tüketici grubu arasinda istatistiksel anlamlı bir fark $\left(\begin{array}{ll}P & >0.05\end{array}\right)$ bulunmamıştır. Geleneksel ürün tüketiciler tarafindan her ne kadar ilk kez deneyimlenmiş olsa da, yabancı olmadıkları bir mutfağın ürünü olduğu için tüketicilerin gıda neofobisinin olup olmamasının duyusal analiz sonuçlarına etki etmediği düşünülmektedir. Onurlubaş ve Taşdan (2017) geleneksel ürünlerin tüketiminde aile büyüklerinin geleneksel gıda tüketim alışkanlıklarının, geleneksel gıdaların besleyici ve sağlıklı olması algisının ve merak etmenin etkili olduğunu saptanmış olup; Türkiye genelinde geleneksel gida tüketme olasıllğını yaklaşık \%98.0 olarak tespit etmiştir. 
Duyusal analiz sonuçlarına göre geleneksel dartı örnekleri genel özellikleri açısından ürünü tanımayan tüketicinin beğenisini kazanmışıtır. Bu panelist grubu tarafindan en az beğenilen özellik ortalama 3.40 puan ile görünüş olmuş ve geleneksel ürünün heterojen, yağlı ve farkl1 görüntüsü olduğu ifade edilmiştir. Bir tüketici, yağ içerisindeki heterojen görüntüden dolayı tahine benzetmiş ve bunu tahinde olduğu gibi bir kusur olarak algıladığını ifade etmiş̧tir. Dartının kıvam olarak dağınık ve yağlı olması sebebiyle ürün ekmekle alınırken veya ekmeğin üzerine koyulurken çekinceler yarattı̆g da ayrı bir görüşs olarak ifade edilmiştir. Geleneksel ürünün kendine has kokusu ortalama 3.89 ile görünüşten sonra en düşük puanı alan duyusal özellik olmuştur. Ürünü tanımayan tüketicilerden bir bölümü gıdanın kokusunu ağır bulduklarını ifade etmişlerdir.

Dartı genel olarak görüntü ve koku açısından ortalama düzeyde puan alsa da; ürünü tanımayan tüketiciler tarafindan tadı sevilmiş ve tat açısından ortalama 4.12 ile en yüksek puanı almıştır. Ekşsimsi diye nitelendirilen tat geleneksel ürünü tanımayan tüketicilerin \%17.2'si tarafindan içerisinde kavrulan süt parçaları sebebiyle kızarmış peynire veya kuymağa benzetilmiştir. Süt yağ1, süt ürünlerinin fiziksel özellikleri, besin değerleri, tat ve aromaları üzerinde önemli rol oynamaktadır (Metin, 2012). Geleneksel dartının tat bakımından yüksek puan alması ve tercih nedeni olması süt yağ1 yönünden yoğun bir ürün olmas1, süt yağından ileri gelen duyusal özellikler ve yağ dışında az miktardaki süt kısmının kavrulması ile oluşan aroma ile açılanabilmektedir.

\section{SONUÇ}

Geleneksel ürünlerden biri olan dartının üretiminin, bazı fiziksel ve kimyasal özelliklerinin ortaya koyulduğu bu çalışmayla, geleneksel ürünün kalitesini kaybetmeden üretilmesi, üretime standart kazandırılması ve coğrafi işaretleme yapılabilmesi için bir kaynak teşkil edeceği düşünülmektedir. Dartı geleneksel bir ürün olduğu için ürünü tanıyan ve tanımayan tüketicilerden duyusal niteliklere ilişkin değerlendirme yapmaları istenmiştir. Geleneksel ürünün duyusal analiziyle ilgili olarak daha ayrıntılı çalısmaların yapılmasına; özellikle duyusal değerlendirme kartlarının oluşturulmasına, ürüne özgü karakteristiklerin ortaya konulmasina ve üründe karşılaşılabilecek kusurlar hakkında daha fazla çalışılmasına ihtiyaç duyulmaktadır. Ayrıca endüstriyel üretim için üretim yönteminin standardize edilmesi, gida güvenliği, raf ömrü ve ambalajlama çalışmalarına yönelik araştırmalara odaklanılması gerekmektedir.

\section{TEŞEKKÜR}

Bu çalışma, Bilecik Şeyh Edebali Üniversitesi Bilimsel Araştırma Projeleri Birimi tarafından "2016-02.BŞEÜ.10-03" proje numarası ile desteklenmiştir.

\section{KAYNAKLAR}

Akalın, A.S., Gönç, S., Ünal, G., Ökten, S. (2006). Determination of some chemical and microbiological characteristics of kaymak. Grasas Aceites, $\quad 57(4)$ : 429-432, doi: 10.3989/gya.2006.v57.i4.70.

Alyakut, Ö., Üzümcü T.P. (2017). Gastronomi turizmi bağlamında Kandıra beslenme kültürü ve unutulmaya yüz tutmuş lezzetleri Goncaaydın köyü örneği. IV. Uluslararası Çoban Mustafa Paşa ve Kocaeli Tarihi-Kültürü Sempozyumu, 24-26 Mart 2017, Kocaeli, Türkiye.

Anonymous (2000). Ash of milk - gravimetric method, Official Methods of Analysis of AOAC International Method 945.46, (33.2.10).

Anonymous (2002). TSE İnek sütü - çiğ standard1 (TS 1018), Türk Standartları Enstitüsü, Ankara.

Anonymous (2003). Türk gida kodeksi. Krema ve kaymak tebliği (2003 /34). Tarım ve Köyişleri Bakanlığı. 27 Eylül 2003 tarih ve 25242 sayılı Resmi Gazete, Ankara.

Anonymous (2008). TSE Süt - azot içeriği tayini (TSE EN ISO 8968-3), Türk Standartlar1 Enstitüsü, Ankara.

Anonymous (2009). Adapazarı dartılı keşkek, Tescil No: 168. http://www.turkpatent.gov.tr/ TURKPATENT/resources/temp/A5D196BF0F97-4330-864A-1BC294CF484F.pdf (Erişim tarihi:11.05.2018). 
Anonymous (2015). T.S.E., Süt-yağ muhtevas1 tayini- gerber metodu (Rutin metod) (TS ISO 2446), Türk Standartları Enstitüsü, Ankara.

Anonymous (2017). Akçakoca melengücceği tatlis1, Tescil No: 279. http://www.turkpatent.gov.tr/TURKPATENT /resources/temp/E6FAF650-8BB8-4866-90F9D3A186A9652B.pdf (Erişim tarihi:11.05.2018).

Belc, N., Duta, D.E., Iorga, E., Mohan, G., Moşoiu, C.E., Vasile, A., Sanmartin, A., Pedrero Torres, M., Martinez, D.Q., Amaro, A., Teixeira, P., Cardos, E., Pintado, M., Ferreira, V., Magalhães, R., Almeida, G. (2016). Food safety aspects concerning traditional foods. In: Emerging and Traditional Technologies for Safe, Healtby and Quality Food, Barbosa-Cánovas, G.V. (chief ed.) Switzerland: Springer International Publishing, pp. 33-54. ISBN: 978-3-319-24040-4.

Cumhur, Ö. (2017). Geleneksel gidaların endüstriyel üretime aktarılması. 1. Uluslararas1 Turizmin Geleceği Kongresi: İnovasyon, Girişimcilik ve Sürdürebilirlik, 28-30 Eylül 2017, Mersin, Türkiye, 1693 s.

Cumhur, Ö. (2018). Geleneksel bir lezzet: Dart1, International Gastronomy Tourism Studies Congress, 20-22 September 2018, Kocaeli, Turkey, $887 \mathrm{p}$.

Dereli, Z., S.evik, R. (2011). Modifiye atmosferde paketlenerek depolanan afyon kaymağında oluşan kimyasal değişimler. Gıda Teknolojileri Elektronik. Dergisi, 6 (2): 1-8.

IBM Corp. Released (2013). IBM SPSS Statistics for Windows, Version 22.0. Armonk, NY: IBM Corp.

Kocaoğlu, E. A. (2009). Ankara'da satışa sunulan kaymakların bazı özellikleri üzerine bir araştırma. Ankara Üniversitesi Fen Bilimleri Enstitüsü Süt Teknolojisi Anabilim Dalı Yüksek Lisans Tezi, Ankara, Türkiye, $47 \mathrm{~s}$.
Metin, M. (2012). Süt teknolojisi, sütün bileşimi ve işlenmesi. Ege Üniversitesi Mühendislik Fakültesi Yayınları, No: 33, 6. Baskı, İzmir, Türkiye, $802 \mathrm{~s}$. ISBN: 9754832792.

Onurlubaş, E., Taşdan, K. (2017). Geleneksel ürün tüketimini etkileyen faktörler üzerine bir araştırma. Bolu Abant İzet Baysal Üniversitesi Sosyal Bilimler Dergisi, 12: 115-132, doi: 10. 11616/AbantSbe.

Öksüz, Ö., Kurultay, S., Simsek, O., Gündoğdu, A. (2000). Tekirdağ ili merkezinde tüketilen kaymakların bazı kimyasal ve mikrobiyolojik özelliklerinin belirlenmesi üzerine bir araştırma. VI. Süt ve Süt Ürünleri Sempozyumu, 22-23 Mayıs 2000, Tekirdağ, Türkiye, 567-570 s.

Pamuk, Ş. (2017). Geleneksel Afyon kaymağ1 üretimi. Atatürk Üniversitesi Vet Bil Derg, 12(1): 8489, doi: 10.17094/ataunivbd.309780.

Pliner, P., Hobden, K. (1992). Development of a scale to measure the trait of food neophobia in humans. Appetite, 19: 105-120, doi: 10.1016/0195-6663(92)90014-W.

Smiddy, M. A., Kelly, A.L., Huppertz, T., (2009). Cream and related products. In: Dairy fats and related products, Adnan Y. Tamime (chief ed.), United Kingdom: Wiley-Blackwell, pp. 61-82. ISBN: 9781-405-15090-3.

Trichopoulou, A., Soukara, S., Vasilopoulou, E., (2007). Traditional foods: a science and society perspective. Trends Food Sci Technol, 18: 420-427, doi: 10.1016/j.tifs.2007.03.007.

Üzümcü T.P., Alyakut Ö. \& Akpulat N.A. (2017). Coğrafi işaretleme kapsamında kocaeli gastronomik ürünlerinin değerlendirilmesi. $K M \ddot{U}$ Sosyal ve Ekonomik Araştırmalar Dergisi, 19 (28): 132-140. 